\title{
$\mathrm{Nd}-\mathrm{Fe}-\mathrm{B}$ 系スプレー造粒粉中の PVA の熱分解挙動
}

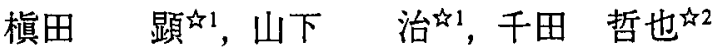 \\ 功1 住友特殊金属(侏研究開発部，广 618-0013 大阪府三島郡島本町江川 2-15-17. \\ 理学電機侏製品事業部, 干 196-8666 昭島市松原町 3-9-12.
}

\section{Thermal Decomposition Behavior of PVA as Organic Binder of Spray Dried Nd-Fe-B System Powder}

\author{
Ken Makita ${ }^{\not 1}$, Osamu Yamashita ${ }^{41}$ and Tetsuya Senda ${ }^{\text {t2 }}$ \\ ${ }^{4} 1$ Research \& Development Department, Sumitomo Special Metals Co., Ltd., 2-15-17 Egawa Shimamoto-cho Mishima-gun, Osaka 618-0013. \\ $4^{2}$ Product Management Division, Rigaku Corporation, 3-9-12 Matsubara-cho, Akishima 196-8666.
}

Received October 22, 1997

\section{SYNOPSIS}

Debinding process under hydrogen atmosphere is effective to eliminate the residual carbon contents in Nd-Fe-B system green body which is compacted by using spray dried powder. But it is not effective for elimination of residual oxygen contents comparatively. The emitted gas from compacted body of Nd-Fe-B system spray dried powder including poly(vinyl alcohol)(PVA) as a binder was analyzed by mass spectroscopy. Much emission of a fragment with $\mathrm{m} / \mathrm{z}=16$ was observed only when spray dried powder was heated under hydrogen atmosphere. The fragment was proved to be methane by gas chromatography. DTA curve measured simultaneously for spray dried powder showed absorption of hydrogen by Nd-Fe-B in the vicinity of $220^{\circ} \mathrm{C}$, and the desorption of hydrogen started above $230^{\circ} \mathrm{C}$. The latter was accompanied by enhancement of the emission of hydrocarbon such as methane. Hydrogen atom sent out from Nd-Fe-B powder would make the fragments from main chain of PVA stable, and accelerates the debinding by vaporization of methane and other hydrocarbon with low mass number. In contrast, degraded sidechain of PVA would immediately combine with neodymium of $\mathrm{Nd}-\mathrm{Fe}-\mathrm{B}$ powder and form $\mathrm{Nd}_{2} \mathrm{O}_{3}$ which remains in the sintered body.

KEY WORDS

Nd-Fe-B magnets, spray drying, poly(vinyl alcohol), mass spectroscopy, gas chromatography

\section{1 緒 言}

実用磁石材料の中で最も高性能な磁石として知られるNd-FeB系焼結磁石”は，パソコンのハードディスクドライブをはじ めとするさまざまな用途に使われている。この磁石の製法は， 母合金を粉砕して得た原料粉末を磁界中で成形した後, 焼結す る粉末治金法によっている.

近年, 磁石を用いた機器の小型化への要求が高まり，寸法の 小さな高性能磁石を用いて磁気回路の小型化がはかられてい る. 小型の磁石をプレス成形で製造する場合に, 製品形状に合 わせて成形に用いる金型の開口部のサイズを小さくすると,給 粉量の変動が大きくなったり, 極端な場合, 原料粉末が金型内 に全く入らなくなったりするため, 原料粉末の流動性を改善す る必要がある。

最近, Nd-Fe-B系磁石の原料粉末の流動性を改善する手段と して，スプレー造粒法による造粒が試みられている2-4).スプ
レー造粒により，原料粉末は数十 $\mu \mathrm{m}$ の径を持つ二次粒子に造 粒され，流動性は著しく改善される.流動性の良いスプレー造 粒粉を用いることにより，例えば1 $\mathrm{mm}$ 以下の厚みのNd-Fe-B系 焼結磁石を高い寸法精度で製造することが可能になったら!

ところで，スプレー造粒法を Nd-Fe-B系焼結磁石の原料粉末 に適用する場合，造粒のために添加した有機バインダーをいか に除去するかが製造上のポイントになる，著者のひとりは，有 機バインダーを含んだNd-Fe-B系原料粉末の成形体を水素中で 加熱，保持すれば，真空中で加熱した場合に比べて残留炭素量 を著しく減少できることを見出しだ'。

このような有機バインダーの熱分解機構に対する雾囲気の影 響については，酸素(または空気) 中と不活性ガス中では多く 研究きれているものの, 水素中での熱分解機構の研究は少な い. 本稿で扱う希土類焼結磁石の製造では，成分である希土類 元素が極めて反応性に富むため，脱バインダーや焼結の雲囲気 
として室素や酸素を用いることができないという事情もある。 そこで, Nd-Fe-B 系スプレー造粒粉にパインダーとして含ま れるポリビニルアルコール (PVA)の水素中での熱分解挙動を 明らかにするために，成形体からの発生ガスの分析を行った。

\section{2 実験方法}

高周波溶解によって作製したNd-Fe-B母合金を機械粉砕後， さらに窒素ガス中でジェットミル粉砕して，平均粒径 $2.9 \mu \mathrm{m}$ の原料粉末を得た，得られた原料粉末の組成は $\mathrm{Nd} 29.7 \mathrm{wt} \%$, Dy $1.0 \mathrm{wt} \%$, B $1.0 \mathrm{wt} \%, 00.45 \mathrm{wt} \%, \mathrm{C} 0.06 \mathrm{wt} \%$, 残部 $\mathrm{Fe}$ であっ た.これに,バインダーとしてポリビニルアルコール (PVA) の $10 \%$ 水溶液を，原料粉末に対して乾燥時のPVA 含有量が 0.2wt\%になるように添加, 混合し, さらに純水を加えて濃度 65\%のスラリーを作製した．実験に用いたPVAの重合度は約 1700 ，ヶン化度は $88 \%$ である。 スラリー中の原料粉末の酸化 防止のため，スラリーの調合はすべて $0 \sim 5^{\circ} \mathrm{C} の$ 温度範囲で 行った.

次に，窒素循環型スプレードライヤーに上述のスラリーを 供給し, 窒素雾囲気中, $75^{\circ} \mathrm{C}$ 乾燥温度でスプレー造粒を 行った，得られたスプレー造粒粉の平均二次粒子径 $\left(\mathrm{D}_{50}\right)$ は $50 \mu \mathrm{m}$ で，二次粒子は球形をしていた．この造粒粉を金型に入 れ，0.88MA/m の磁界中で配向しながら 147MPa の圧力で成形 したものをガス分析試料とした。

発生ガスの分析には示差熱天秤一質量分析計同時測定装置 (TG-DTA/GC-MS) を用いた。この装置はTG-DTA部が赤外線 加熱型 Thermo Plus TG8120(理学電機製), GC-MS 部が HP5890-5971A(Hewlett Packard 製)からなり，試料を加熱しな がら示差熱分析と重量変化を測定すると同時に, 発生ガスの 質量分析を行うことができる。試料には上述の成形体をナイ フで削って作轅した粉体を用い，一回の測定に約 $120 \mathrm{mg}$ を用 いた．PVA 単独の測定には顆粒状のPVAを粉研した試料約 $2 \mathrm{mg}$ を用いた。 測定の雾囲気は水素中，またはへリウムで，昇 温速度は $20^{\circ} \mathrm{C} / \mathrm{min}$ とした。

また，一部の成形体を用いて脱バインダー雾囲気の検討を 以下の条件で行った，成形体を水素流気中，または真空中， $450^{\circ} \mathrm{C}$ で $2 \mathrm{~h}$ 脱バインダー処理し，引き続きアルゴン流気中で $1080^{\circ} \mathrm{C}, 4 \mathrm{~h}$ の焼結を行った後，同じくアルゴン中で $500^{\circ} \mathrm{C}, 2 \mathrm{~h}$ の熱処理を行い，磁石試料を得た。磁石の磁気特性は，試料 をピーク強度 3.2MA $/ \mathrm{m}$ のパルス磁界で着磁した後，BH卜 レーサーで測定した。

\section{3 実験結果}

3.1 焼結体の残留炭素, 酸素量

ここでは，PVAを含むNd-Fe-B系成形体を真空中，または 水素中で脱バインダーした後，焼結して得られた磁石の調查 結果について述べる。

Fig.1に, PVAの添加量を0〜0.2wt\%まで変えて作製したス プレー造粒粉を成形後，真空中，または水素中で脱バイン ダーを行った後，アルゴン中で焼結して得られた焼結体に含
まれる a) 炭素量，b)酸素量の分析值を，スプレー造粒粉の分 析值とともに示す．まず，炭素量について見ると，真空中で 脱バインダーを試みた焼結体の炭素量はスプレー造粒粉の值 とほとんど変わらない。このことから，真空中では脱バイン ダーが進行せず，PVA中の炭素はほとんどが焼結体に残留し ていることがわかる.これに対して，水素中で脱バインダー 処理した焼結体の炭素量はスプレ一造粒前の原料粉末のレベ ルまで低隇しており，水素中での脱バインダーが有効である ことを示している.

つぎに，スプレー造粒粉の酸素量については，PVA中の酸 素の割合 (36.5wt\%)に応じてPVA 添加量とともに増加する。 また，焼結後の酸素量は脱バインダーの雲囲気によらずスプ レー造粒粉よりも増加する。このことは，水素中の脱バイン ダーによっても，PVA中の酸素は除去できずに焼結体中に残 留することを示している．酸素量の增加の程度は真空中の方 が水素中よりも大きいが，これは脱バインダー温度での原料 粉末の酸化が水妻中では抑制されるためと考えられる。

Fig.1に示した焼結体試料について, PVAの添加量と焼結体 の密度，および保磁力の関係を調べた結果，水素中で脱バイ ンダーした焼結体では, $7.5 \mathrm{Mg} / \mathrm{m}^{3}$ 以上の密度と, $1.0 \mathrm{MA} / \mathrm{m}$ 以 上の保磁力が得られ，磁気特性は良好であった。一方，真空 中で脱バインダーしたものはPVA添加量が増加するとともに 密度が低下し, 保磁力はPVA 添加量が $0.03 \mathrm{wt} \%$ (焼結体の炭”

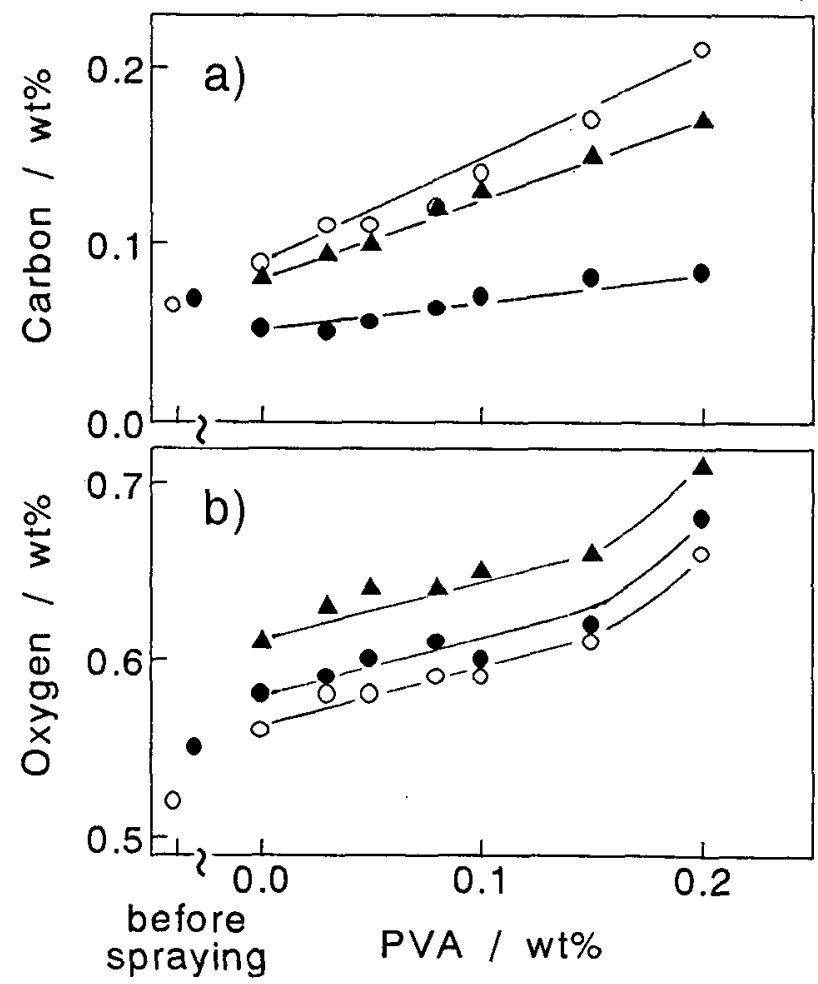

Fig.1 Relation between additional content of PVA in spray dried $\mathrm{Nd}-\mathrm{Fe}-\mathrm{B}$ powder and a) residual carbon or b) oxygen content of spray dried powder $(O)$, sintered magnets debound in vacuum $(\Delta)$, and in $\mathrm{H}_{2}(\boldsymbol{O})$. 
素量 $0.1 \mathrm{wt} \%)$ を越えると急激に低下してほとんどゼロになっ た。これは，残留した炭素が焼結の過程でネオジムと反応し て安定な炭化物を形成し，ネオジム成分の不足が起こった結 果，液相焼結の進行が妨げられたり，保磁力の発生に必要な Ndリッチな粒界相が形成されなかったためと考えられる。

スプレー造粒の目的である流動性の向上の観点からは， PVAの添加量が少なすぎると造粒粉の強度が低下して流動性 が悪くなるため，添加量は最低でも $0.1 \mathrm{w} t \%$ 程度は必要であ る、したがって，造粒粉の流動性を維持しながら磁石の特性 を出すには水素中での脱バインダー処理を行うことが必要と なる。

3.2 スプレー造粒粉からの発生ガス

前節で述べた水素中での脱バインダーがなぜ有効なのかを 考察するため，スプレー造粒粉からの発生ガスを分析した，

Fig.2に, PVAを $0.2 w t \%$ 含むスプレ一造粒粉のa)ヘリウム 中，またはb)水素中でのTG-DTA 曲線と，同時に測定した試 料からの発生ガスのマススペクトルの主要な質量数のピーク 強度の時間変化 (マスクロマトグラム) を示す．図中の TIC (total ion current) はすべてのイオン電流の総和である。まず， ヘリウム中におけるスプレー造粒粉の重量変化 (TG) を見る と， $100^{\circ} \mathrm{C}$ ，および $250^{\circ} \mathrm{C}$ 付近で大きな重量隇少があり， $300^{\circ} \mathrm{C}$ 以上ではなだらかな減少を示す。示差熱曲線(DTA)について は $300^{\circ} \mathrm{C}$ 以上で連続的な吸熱が見られる.ヘリウム中での発生 ガスを見ると， $100^{\circ} \mathrm{C}$ 付近では $\mathrm{H}_{2} \mathrm{O}(\mathrm{m} / \mathrm{z}=18)$ が， $250^{\circ} \mathrm{C}$ 付近で は $\mathrm{m} / \mathrm{z}=29,43$ に相当するガスがそれぞれ検出された. Fig3a)に $320^{\circ} \mathrm{C}$ 付近での発生ガスのマススペクトルを示す. $\mathrm{m} / \mathrm{z}=78,91$ といった質量数の大きなガスが出ていることがわかる，

つきに，水素中でのデー夕(Fig.2b)を見ると，220足をピー クとする特徵的な発熱反応と重量増加が観測された。これら は, Nd-Fe-B 系原料粉末の水素吸蔵反応によるものである。 $250^{\circ} \mathrm{C}$ 以上では弱い吸熱反応が見られ，重量も連続的に減少す る. 水素中での発生ガスは, ヘリウム中の場合と同じ温度域 で $\mathrm{m} / \mathrm{z}=18,29,43$ のピーク強度の増加が見られた他に， $320^{\circ} \mathrm{C}$ 付近に $\mathrm{m} / \mathrm{z}=16$ のピークが出ているのが特徽的である. Fig.3b)

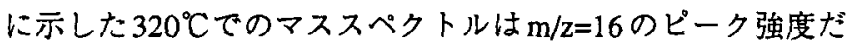
けが強く、ヘリウムの場合 (同図a) と全く巽なっている.

$300^{\circ} \mathrm{C}$ 付近の発生ガスを同定するために，液体窒素による コールドトラップで捕捉した $300^{\circ}$ C付近での試料からの発生ガ スのイオンクロマトグラムを Fig.4に示す，この測定では，系 内の残留酸素からのシグナルを排除するために，縦軸はTIC ではなく $\mathrm{m} / \mathrm{z}=15$ のイオン電流をとっている.ヘリウム䨌囲気 でのクロマトグラム (a)ではエタン, プロパン, イソブタンの 他にベンゼンの存在が確認できた，一方，水素雲囲気でのク ロマトグラム(b)にはプロパン, イソブタンなどの他にメタン のピークが明瞭に観察された。

また，対照実験としてPVAを全く添加せずにスラリーにし た後，スプレードライヤーで乾燥させた Nd-Fe-B 系原料粉末 についても，Fig.2 と同樣の測定を行った，その結果，水素中 でのNd-Fe-B粉末の水素化は起こったものの，ヘリウム中, 水 素中のいずれの雲囲気中でもメタンの発生は検出されず，粉
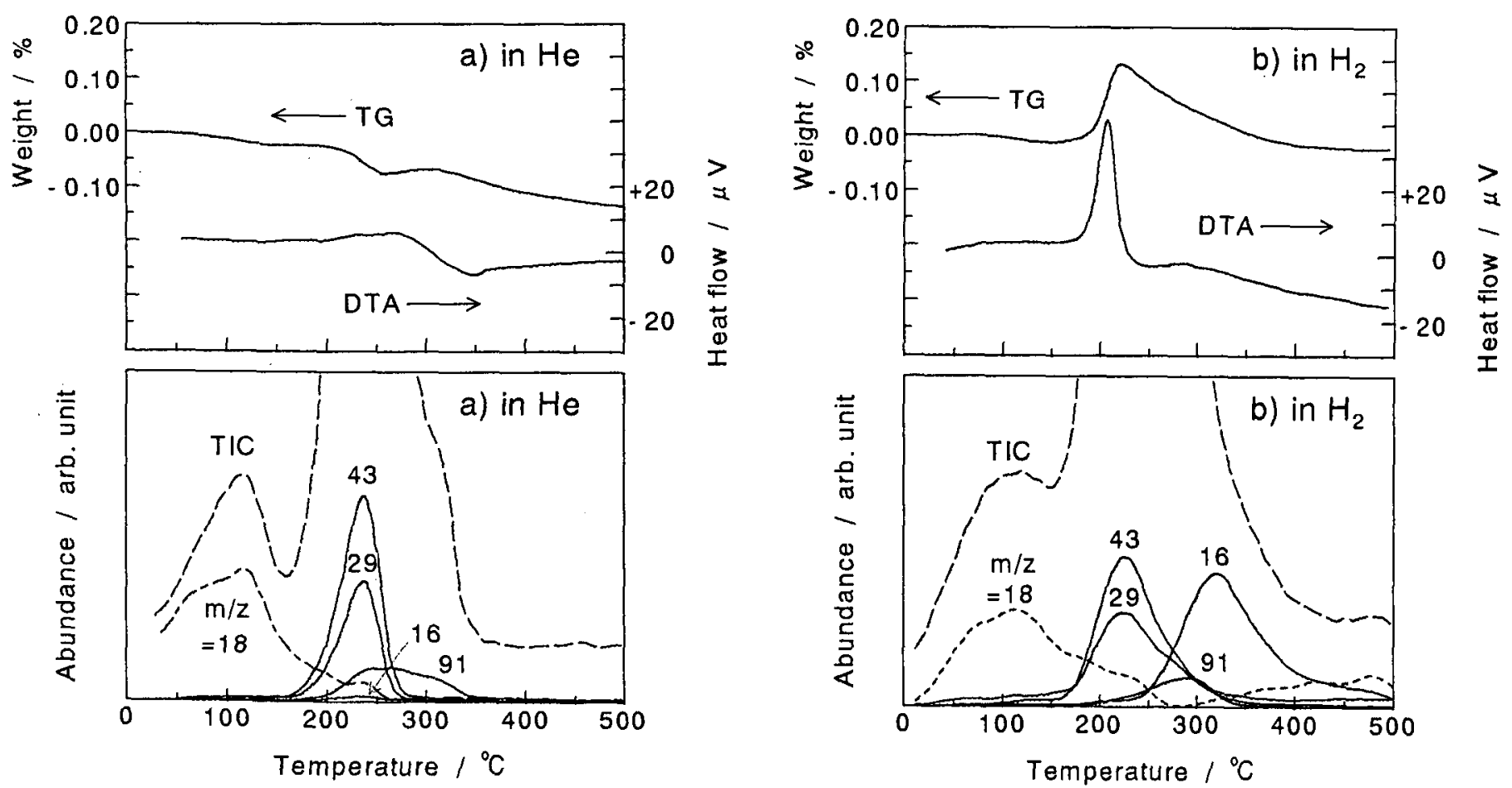

Fig.2 Thermogravimetry (TG) curves and differencial thermal analysis (DTA) curves of Nd-Fe-B system spray dried powder heated a) in He gas, and b) in $\mathrm{H}_{2}$ gas. Mass chromatograms of emitted gas with mass numbers $\mathrm{m} / \mathrm{z}=16,18,29,43,91$ were measured simultaneously by mass spectrometer (MS), and indicated with the same temperature axis. TIC indicates total ion current of MS. Heating rate is $20^{\circ} \mathrm{C} / \mathrm{min}$. 

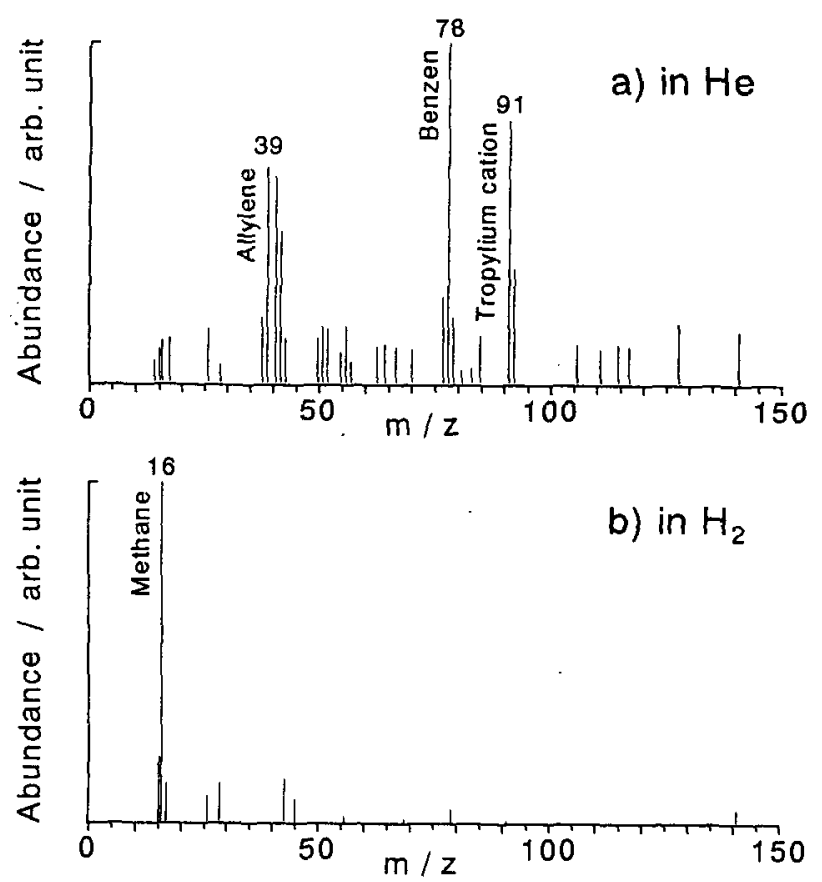

Fig.3 Mass spectra of emitted gas from Nd-Fe-B system spray dried powder at $320^{\circ} \mathrm{C}$ heated a) in $\mathrm{He}$ gas, and b) in $\mathrm{H}_{2}$ gas.
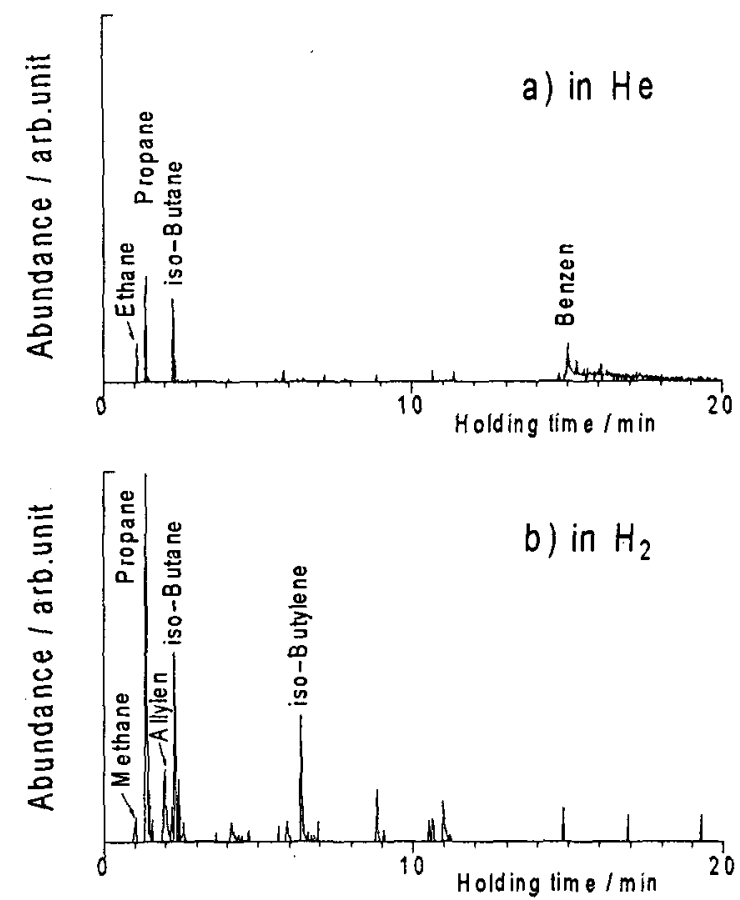

Fig.4 Ion chromatograms of emitted gas with $m / z=15$ from $\mathrm{Nd}$ $\mathrm{Fe}-\mathrm{B}$ system spray dried powder trapped at $300^{\circ} \mathrm{C}$. Heating atmospheres are a) in $\mathrm{He}$, and b) in $\mathrm{H}_{2}$.

体から発生したと思われる水蒸気 $(\mathrm{m} / \mathrm{z}=18)$ が主な検出ガスで あった。

以上の結果から，PVAを含むNd-Fe-B系のスプレー造粒粉 からの発生ガスを不活性ガス中と水素中の二つの雲囲気で比

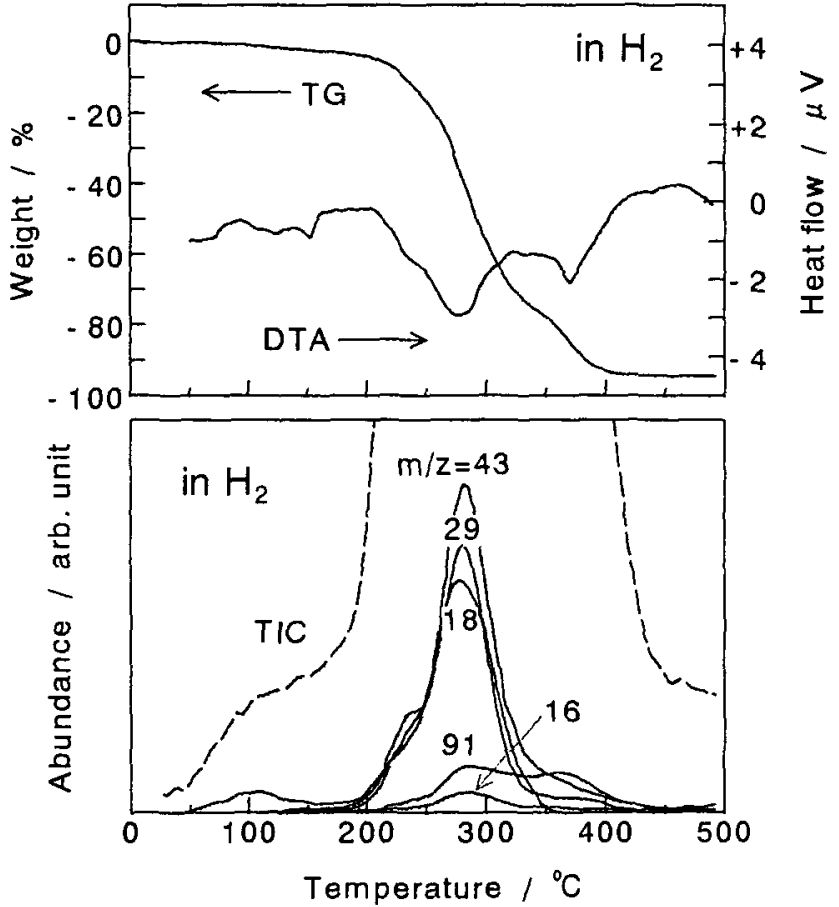

Fig.5 TG and DTA curves of PVA heated in $\mathrm{H}_{2}$ gas. Mass chromatograms of emitted gas are indicated in the same temperature axis. TIC indicates total ion current. Heating rate is $20^{\circ} \mathrm{C} / \mathrm{min}$.

較すると,水素中でのみ $230^{\circ} \mathrm{C}$ 以上の温度域でメタンガスが多 く検出されることがわかった。

3.3 PVAの熱分解挙動

PVAを単独で昇温したときの熱分解挙動を調查した. Fig.5 に水素中でのTG-DTA曲線と発生ガスのマスクロマトグラム を示す.PVAの熱分解によると思われる重量減少と吸熱が二 段階で起こっていることがわかる. 低温側の熱分解で元の重 量の 70\%以上が失われる. 各段階での発生ガスの内訳を見る と, 低温側では $\mathrm{m} / \mathrm{z}=18,29,43$ などのガスが, 高温側では $\mathrm{m} /$ $\mathrm{z}=91$ のガスの発生が観測された。また, PVA単独の測定では, スプレー造粒粉で見られたような $100^{\circ} \mathrm{C}$ 付近での水蒸気の発生 はなく, PVAの分解時に水蒸気が発生しているのが特徵的で ある、ヘリウム中で同様な測定を行うと，発生ガスの種類と ピークの温度はTable 1に示すように水素中と同傾向であった。

以上の結果から，PVA 単独の測定では，水素中でのスプ レー造粒粉からの発生ガスに見られたようなメタンの顕著な 発生は確認できなかった。

\section{4 考察}

これまでの測定結果からわかったPVAの熱分解挙動をまと めて Table 1 に示す．この表から PVAの分解ガスとしてメタ ンが多く発生するためには，

(1)水素霝囲気であること

(2) Nd-Fe-B 粉末が共存すること 
Table 1 List of fragments detected by MS in emitted gas from spray dried powder and PVA itself. Temperatures at which fragment ion peaks become their maximum are indicated in centigrade.

\begin{tabular}{|c|c|c|c|c|c|c|c|c|}
\hline \multirow[b]{2}{*}{ Sample } & \multirow[b]{2}{*}{ Atmosphere } & \multicolumn{7}{|c|}{ Major fragments } \\
\hline & & $\begin{array}{l}\mathrm{m} / \mathrm{z} \rightarrow \\
\text { ions } \rightarrow\end{array}$ & $\begin{array}{c}18 \\
\mathrm{H}_{2} \mathrm{O}^{+*}\end{array}$ & $\begin{array}{c}60 \\
\mathrm{C}_{2} \mathrm{H}_{4} \mathrm{O}_{2}{ }^{+*}\end{array}$ & $\frac{16}{\mathrm{CH}_{4}^{+}}$ & $\frac{29}{\mathrm{C}_{2} \mathrm{H}_{5}^{+\cdot}}$ & $\begin{array}{c}43 \\
\mathrm{C}_{3} \mathrm{H}_{7}^{+}\end{array}$ & $\frac{91}{\mathrm{C}_{7} \mathrm{H}_{7}^{+}}$. \\
\hline Spray dried powder & $\mathrm{He}$ & & 118 & - & - & 238 & 238 & 268 \\
\hline Spray dried powder & $\mathrm{H}_{2}$ & & 116 & - & 323 & 228 & 232 & 294 \\
\hline PVA only & $\mathrm{He}$ & & 324 & 324 & - & 326 & 326 & 424 \\
\hline PVA only & $\mathrm{H}_{2}$ & & 332 & 332 & - & 335 & 335 & 433 \\
\hline
\end{tabular}

a) PVA<smiles>CCC(CO)C(CC)OC(C)=O</smiles>

b) Side-chain elimination

$$
-(\mathrm{CH}=\mathrm{CH})_{1+\mathrm{m}}-+1 \cdot \mathrm{HO}^{\circ}+\mathrm{m} \cdot \mathrm{CH}_{3} \mathrm{COO}^{\circ}
$$

c) Main-chain fragmentation

$$
\begin{aligned}
-(\mathrm{CH}=\mathrm{CH})_{n}- & +\mathrm{C}_{2} \mathrm{H}_{4}+\mathrm{C}_{3} \mathrm{H}_{8}+\mathrm{C}_{4} \mathrm{H}_{10} \\
& +\mathrm{C}_{7} \mathrm{H}_{7}^{+}
\end{aligned}
$$

d) Radical depolymerization

$$
\begin{gathered}
-(\mathrm{CH}=\mathrm{CH})_{\mathrm{n}}-\quad+\mathrm{Nd}_{2} \mathrm{Fe}_{14} \mathrm{BH}_{\mathrm{x}} \\
\rightarrow-(\mathrm{CH}=\mathrm{CH})_{\mathrm{n}-1}^{\cdot}-\mathrm{CH}_{4}+\mathrm{Nd}_{2} \mathrm{Fe}_{14} \mathrm{~B}
\end{gathered}
$$

e) Oxidation of neodymium

$$
\begin{aligned}
& \mathrm{HO}^{*}+\mathrm{Nd}^{-} \mathrm{Nd}_{2} \mathrm{O}_{3}+\mathrm{H}^{\cdot} \\
& \mathrm{CH} 3 \mathrm{COO}^{-}+\mathrm{Nd}+\mathrm{H}^{-} \rightarrow \mathrm{Nd}_{2} \mathrm{O}_{3}+\mathrm{C}_{2} \mathrm{H}_{4}
\end{aligned}
$$

Fig.6 Chemical structure and thermal decomposition behavior of PVA as a binder of Nd-Fe-B system spray dried powder.

の二つの条件が必要であることがわかる.メタンの発生機構 を考える上で，Nd-Fe-B 粉末が水素化していることがポイン トであるように思われるので，この点に着目してPVAの熱分 解機構を考察する。

$\mathrm{Nd}-\mathrm{Fe}-\mathrm{B}$ 系原料粉末の主相である $\mathrm{Nd}_{2} \mathrm{Fe}_{14} \mathrm{~B}$ の水素化挙動に ついては多くの研究がある ${ }^{8,9} . \mathrm{Nd}_{2} \mathrm{Fe}_{14} \mathrm{~B}$ の試料を水素中で昇 温すると $220^{\circ} \mathrm{C}$ で最初の水素吸蔵反応が起こる。ここでは $\mathrm{Nd}_{2} \mathrm{Fe}_{14} \mathrm{~B}$ の格子間に水素原子が侵入して格子定数の増加がお
こるが, 結晶構造自体は変化しない、また，一旦吸藏された 水素は $220 \sim 400^{\circ} \mathrm{C}$ の温度域で再び徐々に放出される.

本研究に扔いて Nd-Fe-B 系原料粉末の水素吸蔵による重量 増加はFig.2b) から少なくとも $0.14 \%$ と見積もられ，これは $\mathrm{Nd}_{2} \mathrm{Fe}_{14} \mathrm{~B}$ の組成式あたり平均 1.5 個以上の水素原子を吸蔵した ことに相当する。同図のDTA 曲線は $230^{\circ} \mathrm{C} て ゙$ 発熱から吸熱に 転しているので，これ以上の温度域では Nd-Fe-B 粉末に一旦 吸蔵された水素の放出が始まると考えられる．興味深いこと に,この $230^{\circ} \mathrm{C}$ という温度は, $\mathrm{m} / \mathrm{z}=16,91$ のフラグメントの強 度が増加を始める温度とまさに一致している。また，Fig.2の a) と b) で $\mathrm{m} / \mathrm{z}=29,43$ のフラグメントの強度の変化を詳細に比 較すると、a)ではこれらのガスの放出が $270^{\circ} \mathrm{C}$ 以上では見られ なくなるのに対し，b)では弱まり始めた $\mathrm{m} / \mathrm{z}=29,43$ のガスの 放出が $230^{\circ} \mathrm{C}$ 以上で再び盛んになり， $350^{\circ} \mathrm{C}$ 付近まで継続して いることがわかる。このことから, Nd-Fe-B粉末からの水素の 放出に伴って，メタン，およびより大きな分子量を持つガス の脱離が促進されるものと考えられる。

本研究に用いたPVAの分子式を Fig.6(a) に示す．この上う な高分子の熱分解では，側鎖である水酸基や酶酸基が脱離し やすく(b)，ついで，主鎖の部分が環化，脱離，あるいは解重 合を繰り返して分解していく(c). 発生ガス中に $\mathrm{C}_{2} \mathrm{H}_{5}{ }^{+}(\mathrm{m} / \mathrm{z}=29)$, $\mathrm{C}_{3} \mathrm{H}_{7}^{+*}(43), \mathrm{C}_{7} \mathrm{H}_{7}{ }^{+*}(91)$ などが検出されたことは, これらの機構 で生成したPVAの分解生成物が系外に放出されていることを 示している。また, Nd-Fe-Bからの水素の供給のない条件では メタンの発生量が少ない理由は, Fig.6b)に示すように側鎖が 脱離した後の主鎖では炭素原子が一つ置きに二重結合してお $\eta, \mathrm{C}_{2}$ 級以上の炭化水素が解離しやすいためと推測される.

スプレー造粒粉を水素中で昇温し，Nd-Fe-B 粉末が吸蔵し た水素が粉末の表面から徐々に放出されている状態では，放 出直後の水素は雾囲気の水素分子と異なり原子状態であるた め，やはり粉末表面に付着している分解途中のPVAに含まれ るラジカルとすぐさま結合し，ラジカル間の再結合を妨げる はたらきをする，このため，蒸気圧の高い低級の炭化水素が 多く生成され，脱バインダーが進行しやすくなると考元られ る. また, (d)の反応に扔ける生成物の一つはラジカルなので, 
水素原子の供給が続く限り全体の反応は連鎖的に進む ${ }^{10)}$ 。こ のようにして，PVAが完全に分解するまで脱バインダーは主 としてメタンの放出によって起こると考えられる.

つぎに，側鎖の生成物である水酸基と酢酸基について見る と，これらの側鎖が脱離すると不対電子を持つラジカルにな るが,これらのラジカルは非常に反応性が強いため Nd-Fe-B 粉末中のネオジムと結合してしまうと考えられる(Fig.6e). そ の証拠として，スプレー造粒粉の発生ガスではPVA単体の発 生ガスとは対照的に，炭化水素の発生時に側鎖生成物である $\mathrm{H}_{2} \mathrm{O}^{+\cdot}(\mathrm{m} / \mathrm{z}=18)$ と $\mathrm{CH}_{3} \mathrm{COOH}^{+*}(60)$ の発生が見られないことが挙 げられる．特にスプレー造粒粉を水素中で昇温した場合 (Fig.2a)), $230^{\circ} \mathrm{C}$ 以上で $\mathrm{H}_{2} \mathrm{O}^{+\cdot}(18)$ の発生が顕著に低減している が，これは水素を放出した直後の Nd-Fe-B 粉末の表面で酸素 を含んだ側鎖ラジカルによるNdの酸化が促進されることを示 唆している。

これまでの推論から得られたPVAの熱分解機構のモデル (Fig.6)によれば，水素中での脱バインダーが有効である理由 や，PVAに含まれる酸素原子が焼結体中に残留する理由をよ く説明できる。

$$
5 \text { ま め }
$$

ポリビニルアルコール (PVA) をバインダーとした Nd-Fe-B 系スプレー造粒粉からの発生ガスを示差熱天秤一質量分析計 同時測定装置で分析した結果, 脱バインダー挙動について以 下の結論を得た。

1. 水素中で脱バインダー処理を行うと, Nd-Fe-B 粉末に一旦 吸蔵された水素が放出され，PVAから脱離したメチル基と 結合し安定なメタンを生成する結果, 脱バインダーがス ムーズに進行し, 焼結体中に残留する炭素の量を低減する ことができる。

2. PVAを単独で水素中で加熱した場合には1.の反応は起こら ない.
3. 側鎖の脱離によって生成した水酸基と酢酸基は,すぐさま ネオジムと反応してこれを酸化させるため, PVA中の酸素 原子はす心゙て焼結体中に残留する。

水素を用いた脱バインダー処理は，本研究で述べた Nd-FeB系磁石材料以外にも，水素を吸収，放出する金属，あるい は金属間化合物においても有効であると考えられ，今後多く の材料への応用が期待される。

\section{文献}

1) M.Sagawa, S.Fujimura, N.Togawa, H.Yamamoto and Y.Matsuura: "New material for permanent magnets on a base of Nd and Fe (invited)", J. Appl. Phys., 55(1984)2083-2087.

2）山下治, 岸本芳久: "スプレー造粒粉を用いた Nd-Fe-B 焼 結磁石の磁気特性", 粉体および粉末治金, 43(1996)249-255.

3）山下治, 岸本芳久: "スプレー造粒粉を用いた Nd-Fe-B 焼 結磁石の磁気特性 (II )", 粉体および粉末治金, 43(1996) 675-681.

4) 岸本芳久,山下治: "スプレー造粒粉を用いた Nd-Fe-B 焼 結磁石の磁気特性（III )", 粉体および粉末治金, 44(1997) $775-780$

5）桙田顕,山下治,中西昭男: "薄肉成形した Nd-Fe-B 系焼 結磁石の磁気特性", 日本応用磁気学会誌,22(1998)365-368.

6) 山下治: "金属射出成形で作製したNd-Fe-B 磁石の磁気特 性", 粉体抢よび粉末治金, 42(1995)1073-1078.

7) 有井忠,千田哲也："示差熱天秤一質量分析計同時測定装 置 (TG-DTA/GC-MS) に上る熱分解の分析法と高分子材料 への応用 ", 理学電機ジャーナル, 25(1994)41-49.

8) G.Wiesinger and G.Hilscher: Handbook of Magnetic Materials Vol.6, K.H.J.Buschow ed., North-Holland, (1991)543.

9) J.M.Cadogan and J.M.D.Coey: "Hydrogen absorption and desorption in $\mathrm{Nd}_{2} \mathrm{Fe}_{14} \mathrm{~B} "$, Appl. Phys. Lett., 48(1986)442-444.

10) W.Schnabel: 高分子の少化, 相馬純吉訳, 裳華房, (1993)24. 